\title{
Tverrfaglig, prosjektbasert innføring i statistikk på universitetsnivå
}

\author{
H. Vinje, og K. F. Frøslie, \\ Fakultet for kjemi, bioteknologi og matvitenskap, Norges miljф- og biovitenskapelige universitet, As
}

\begin{abstract}
Forståelse for statistikk og kvantitativ forskningsmetode er en av bærebjelkene i kunnskapservervelse og -kommunikasjon innen naturvitenskapene. Anvendelse av statistikk er i sin natur tverrfaglig, og forutsetter samarbeid på tvers av domener. For å kunne frembringe ny kunnskap, er det nødvendig å kombinere domenekunnskap fra andre fagfelt med gode analysemetoder og forståelse for resultatene av disse. For å gjøre studentene i stand til å løse komplekse, reelle utfordringer etter endt studium, må vi jobbe med komplekse problemstillinger også under utdannelsen. Et pilotprosjekt med prosjektbasert undervisning ble introdusert i innføringskurset i statistikk på NMBU høstsemesteret 2018. Læring skulle tilegnes gjennom større prosjekter, med data fra andre fag og fagfelt. De fleste som går innføringskurset $i$ statistikk på NMBU skal ikke bli statistikere, og arbeidsmetoden i et slikt prosjektbasert kurs reflekterer mer realiteten når de senere skal bruke statistikk som domeneeksperter. Våre erfaringer og observasjoner tyder på at å gå fra et tradisjonelt introduksjonskurs i statistikk til et prosjektbasert kurs, kan øke motivasjonen til studenter som ikke selv motiveres av teoretiske fagfelt som statistikk.
\end{abstract}

\section{INTRODUKSJON}

For å gjøre dagens studenter i stand til å løse komplekse, reelle utfordringer etter endt studium, må de eksponeres for komplekse problemstillinger også under utdannelsen (Miller, 2010; Ledford, 2015). Blant utdanningsinstitusjoner og undervisere er fokuset på tverrfaglighet synligere enn noen gang. De nye lærerplanene for grunnskolen (Udir, 2020) har «Tverrfaglige temaer» som eget oppslag under samtlige fag. Ved Norges teknisk-naturvitenskapelige universitet (NTNU) er tverrfaglighet et fokusområde i den nye satsningen «Fremtidens teknologistudier» (NTNU, 2020), og Norges miljø- og biovitenskapelige universitet (NMBU) har tverrfaglighet som et hovedområde i sin strategi (NMBU, 2019).

Teknologi gjør det nå mulig å generere store mengder data i de fleste fagfelt. Men ny innsikt forutsetter at domenekunnskap fra spesifikke fagfelt kombineres med gode analysemetoder og kyndig tolkning. Anvendt statistikk er i sin natur tverrfaglig (Ben-Zvi, 2007; Vance \& Smith, 2019), og forståelse for statistikk og kvantitativ forskningsmetode er på denne måten en av bærebjelkene i kunnskapservervelse og -kommunikasjon innen naturvitenskapene.

I et pilotprosjekt på NMBU høstsemesteret 2018 ble en gruppe studenter tilbudt prosjektbasert undervisning i innføringskurset i statistikk, STAT100. Læring skulle skje gjennom tre større prosjekter, og to av prosjektene var basert på data fra andre fagfelt. De færreste som tar STAT100 skal bli statistikere. Ferske kandidater skal i stedet bruke statistikk på data fra sitt eget fagfelt, og prosjektbasert læring vil derfor reflektere en fremtidig arbeidssituasjon, der de må tenke og jobbe på tvers av fagområder.

Målet med fremlegget er å presentere resultater fra det prosjektbaserte kurset, hovedtrekk fra kvalitative intervjuer som ble gjort i etterkant, samt reflektere rundt tverrfaglighet i utdanning.

\section{MATERIALE OG METODE}




\section{1 kurset}

STAT100 gis hvert semester, og dekker temaene deskriptiv statistikk, sannsynlighetsteori, estimering, hypotesetesting, bivariate analyser, enveis variansanalyse (ANOVA) og enkel regresjonsanalyse. Kurset er obligatorisk for de fleste av de 5500 studentene ved NMBU, og tas av ca 600 studenter årlig.

Pilotprosjektet med prosjektbasert undervisning ble introdusert med egen kurskode (STAT101) høsten 2018. Læringsmålene var de samme som for STAT100, og de tre første ukene fulgte studentene samme undervisning som STAT100-studentene (sannsynlighetsteori og stokastiske variabler). Deretter var målet at STAT101-studentene skulle oppnå det samme læringsutbytte som i det vanlige introduksjonskurset, men ved å gjennomføre tre større prosjekter på egen hånd.

Det første prosjektet omhandlet utvalgsteori, estimering av parametere og usikkerheten rundt estimeringen. Dataene til prosjektet ble simulert, og var en fiktiv meningsmåling fra et fiktivt land. Oppdraget var å lage en film (nyhetssending) der studentene skulle presentere resultatene og implikasjonene av meningsmålingen.

Prosjekt to omhandlet hypotesetesting av to og flere kategoriske variabler hvor de både brukte T-tester og enveis ANOVA. Her ble det tatt utgangspunkt i masteroppgaven «En studie av klimaendringenes påvirkning på nedbrytning av plantemateriale i et alpint miljø» skrevet i Naturforvaltning i 2017 av Ellen Haakonsen Karr (Karr, 2017). Dataene ble forenklet og tilpasset til undervisningen. Oppdraget var å 1) bruke dataene fra prosjektet til EH Karr til å komme frem til egne resultater, 2) trekke konklusjoner på bakgrunn av resultatene, 3) presentere arbeidet i form av en skriftlig rapport til FNs klimapanel, og 4) presentere rapporten for resten av studentene.

I prosjekt tre brukte studentene egne data samlet inn fra et introduksjonskurs i mikrobiologi (BIO130). Oppdraget lød:

«I BIO130 (Generell mikrobiologi I) gjør man flere laboratorieфvelser. Man ser på sammenhenger og prøver å forklare «litt av verden». Dette kan man klare enda bedre ved å inkorporere mer statistikk i laboratorierapportene etter фvelsen.

Labøvelse5 (Bestemme celletall og cellemasse $i$ en bakteriekultur for å kunne lage en standardkurve) $i$ BIO130, går på å bestemme antall celler $i$ en bakteriekultur. Det å finne celletall ved innstøpingsmetoden er en arbeids- og tidskrevende metode å utføre. Bakteriekulturen skal ofte brukes med en gang og det å vente flere timer er ikke фnskelig/mulig. Derfor ser man på sammenhengen mellom en annen metode, absorbans $(O D)$, og celletallet man får fra innstøpingsmetoden (CFU) i seks ulike cellekonsentrasjoner fra den samme bakteriekulturen. Håpet er at den lettere og direkte metoden med å måle absorbans $(O D)$ vil gi et realistisk bilde på antall bakterier og at denne metoden kan brukes direkte.

Dere skal forbedre labboppgaven til neste års BIO130 studenter. Dere skal 1) Skrive om labboppgaven (legge til noe på slutten) slik at den inkluderer en liten statistisk analyse av dataen til slutt. 2) Lage en undervisningsfilm til BIO130 studentene som forklarer teorien bak regresjonsanalyse. (MAX 10 minutter) 3) Lage en eksempelrapport på hvordan det kan gjøres (gjerne med deres egne data fra kurset).»

\subsection{Deltagerne}

Rekrutteringen ble gjort blant alle STAT100-studentene høstsemesteret 2018. Alle studentene fikk først tilbud om å ta Utdanningstesten (Brovold H., 2016), som gir deg en indiksjon på «hvordan du lærer best». Vi oppfordret studenter som ifølge Utdanningstesten likte å tilnærme seg stoffet «ovenfra og ned», samt studenter som i utgangspunktet visste at de likte å jobbe prosjektbasert, til å søke seg over til STAT101. For å bli vurdert, måtte de skrive en søknad om hvorfor de ønsket prosjektbasert undervisning. Vi fikk også informasjon om studentenes matematikkbakgrunn fra videregående (fag og karakterer). STAT101 ble så gjennomført med 8 studenter som var motiverte og hadde reflektert over hvorfor de ønsket nettopp dette kursformatet. Av de 8 var det 3 som hadde meldt seg opp til kurset fra før, men meldt seg av eller ikke oppnådd ønskelig resultat. De åtte ble tilfeldig fordelt i to grupper som de jobbet med gjennom kurset. 
After the title and author(s) and affiliation section, the paper directly starts with the Abstract, followed by the consecutively numbered main chapters. Make sure you include methods, reflections and results. For further advice see the letter of acceptance. Include a list of references at the end of the manuscript.

\subsection{Oppfølging av studentene underveis}

Hvert prosjekt varte i tre uker. I hver prosjektperiode var faglærer tilgjengelig to timer, to ganger i uken gjennom hele prosjektperioden. Det var kun obligatorisk å møte opp første og siste gang av hver prosjektperiode. Hvis studentene ønsket det, hadde de tilgang til et rom på campus som var designet for prosjektjobbing. Studentene valgte både oppmøte og tilgang til rom, og brukte samtlige tilgjengelige timer sammen med faglærer, og i diskusjon med sin egen gruppe. Etter endt prosjektperiode hadde vi en time med formativ evaluering. Her presenterte studentene prosjektene og resultatene sine for hverandre og vi diskuterte rundt disse. Denne evalueringen telte ikke på sluttkarakter, men la grunnlag for diskusjonen vi skulle ha på den muntlige eksamensdelen i slutten av kurset.

Selv om vi ønsket en fri tilnærming til introduksjonsstoffet i statistikk, var vi opptatt av å beholde den faglige tyngden. I slutten av hver prosjektperiode hadde vi derfor regneøvelser der STAT101-studentene løste de samme øvingsoppgavene som STAT100-studentene, og svarte på obligatoriske flervalgsoppgaver med fokus på bakenforliggende teori og utregninger.

\subsection{Eksamen}

Eksamen i STAT100 besto av et sett med 20 flervalgsoppgaver (50\% av karakteren), og et sett med skriftlige oppgaver (inkludert en lengre fritekstoppgave) (50\% av karakteren). Flervalgsoppgavene skulle teste regnekunnskaper og basiskunnskaper i statistikkfaget.

I eksamen i STAT101 fikk studentene de samme 20 flervalgsoppgave som i STAT100 $(50 \%$ av karakteren), men i stedet for skriftlige oppgaver, var 50\% av karakteren basert på en muntlig presentasjon og utspørring basert på ett av de tre prosjektene. Denne løsningen ble valgt for å oppnå bedre samstemt undervisning; at eksamen bedre reflekterte arbeidsmåter og prosesser i kurset (Biggs, Tang, 2011). I den muntlige utspørringen møtte studenten alene. Hen presenterte først det gruppa hadde gjort, og ble deretter eksaminert mer inngående om hvordan de hadde kommet frem til konklusjonene.

\subsection{Kvalitative intervjuer}

I perioden 1-2 måneder etter sensur, ble samtlige STAT101-kandidater intervjuet om deres opplevelse av å følge prosjektbasert undervisning, hvordan denne undervisningsformen påvirket deres motivasjon i kurset. De ble også forelagt en ordinær, skriftlig regresjonsoppgave, og bedt om å beskrive hvordan de ville gått frem for å løse et slikt problem. Intervjuet ble gjort av en person som ikke var tilknyttet kurset, for at ikke studentenes lojalitet til faglærerne skulle påvirke svarene deres.

\section{EVALUERING OG RESULTATER}

Sju av de åtte STAT101-studentene gjennomførte eksamen. Frafallet skyldtes sykdom. På den muntlige delen lå snittet på mellom B og C. På flervalgsoppgavene var gjennomsnittlig poengsum 15 riktige av 20. De 197 STAT100-studentene hadde en gjennomsnittlig poengsum på 15,1 på de samme flervalgsoppgavene.

Matematikkbakgrunnen til deltagerne var varierende, både resultatmessig og nivåmessig. De fleste gikk naturvitenskaplige retninger som ikke krevde mer matematikk enn innføringskurset i matematikk (MATH100 på NMBU), eller R2 fra videregående.

I intervjuene etter kurset ble det også rapportert om varierende grad av matematikk-kunnskaper, og ikke minst motivasjon for realfag som statistikk og matematikk. Fraser som ble brukt var «har ikke et mattehode», «har aldri gjort det bra i fag med mye tall» eller «det var noe han var god på og vi andre prøvde å følge med på hva som skjedde». 
I intervjuene ble det videre rapportert at de hadde lært mye og fått mer motivasjon for statistikkfaget. Flere studenter påpekte at de tydelig hadde sett nytten av faget og det tette forholdet mellom domenekunnskap og statistisk metode. Prosjekt tre ble dratt oftere frem enn de to andre som spennende, lærerikt og motiverende. Det var dette prosjektet der datainnsamling og domenekunnskap lå nærmest de fagene flere av deltakerne studerer. I intervjuene ble det også rapportert om at STAT101 var et tidkrevende fag, at det tok mye tid og energi fra andre fag, både fordi det var større prosjekter over lengre perioder, men også fordi det var mange nye aspekter ved læringen som tok mye ekstra tid. Noe av det som ble sett på som krevende, var at problemstillinger kom fra andre fagfelt enn det de selv studerte, at de måtte sette seg inn i og bruke R/RStudio, og at de brute mye tid til filming/klipping og forberedelser til presentasjoner.

Prøveprosjektet resulterte i et undervisningssamarbeid mellom statistikk- og mikrobiologimiljøet ved NMBU, for å lage tverrfaglige læringsressurser til bruk i begge fagfelt.

\section{DISCUSSION}

Prosjektbasert undervisning ble introdusert først og fremst som en del av et større pedagogisk prosjekt om hvordan man kan tilpasse statistikkopplæring til en større og mer homogen studentmasse, slik vi møter i akademia i dag og ikke minst i introduksjonskurset i statistikk ved NMBU (Sæbø, Almøy, \& Brovold, 2015; Vinje, Almøy, Brovold, \& Sæbø, 2019). Samtidig reflekterer en slik måte å jobbe på i mye større grad hvordan studenter ved NMBU og andre universiteter møter statistikk i videre utdanning eller i arbeidslivet, og en slik tilnærming til faget vil derfor være nyttig og relevant for de fleste.

Våre erfaringer og observasjoner tyder på at å gå fra et tradisjonelt introduksjonskurs i statistikk til et prosjektbasert kurs, kan øke motivasjonen til studenter som ikke selv motiveres av teoretiske fagfelt som statistikk. Flere av de som gjennomførte det prosjektbasert kurset rapporterte at det var en mer motiverende innfallsvinkel for dem å jobbe med større prosjekter. Dette styrkes av at prosjekt tre spesielt trekkes frem som det desidert mest spennende blant studentene. Prosjekt tre lå nærmest opp til studentenes studier, og flere av studentene hadde selv vært med på å generere data gjennom en laboratorie øvelse i innføringskurset i mikrobiologi. Samtidig var dette prosjektet det siste, og studentene hadde derfor lært mer statistikk før de satte i gang med analysen. Det kan også virke motiverende. Et annet moment er at selve den statistiske metoden i dette prosjektet (regresjonsanalyse) oppfattes som spesielt motiverende. Lineær regresjon ligger nært opp til matematiske begreper som har vært kjent siden ungdomsskolenivå, og erfaring fra innføringskurs i statistikk tilsier at dette er et takknemlig tema å undervise.

Det at studentene presterer godt på den muntlige eksamensdelen er ikke så overraskende. De har diskutert sammen i grupper og med faglærere gjennom hele kurset. Situasjonen er kjent for dem, de har $\emptyset$ vd mye og selvsikre. Det er også vist at man i gjennomsnitt gjør det bedre på muntlig eksamen kontra skriftlig (Huxham, Campbell, \& Westwood, 2010). STAT101-studentene gjorde det også like bra på flervalgsoppgavene som sine STAT100 medstudenter. Det var en bekymring da vi opprettet kurset, hvorvidt vi klarte å opprettholde samme faglige nivå som STAT100, altså om studentene ville tilegne seg ikke bare det praktiske bruksområdet til metodene, men også teorien bak. Siden det var kjent at flere av de som tok STAT101 hadde prøvd seg på statistikk før og/eller meldte om manglende motivasjon for «fag som dette», var det dermed betryggende at de oppnådde samme gjennomsnittsscore som studentene i STAT100. Om det skyldes at de har deltatt i undervisning som motiverer dem til å jobbe mer med faget, eller om prosjektbasert kurs gjør at innholdet i faget er lettere tilgjengelig for dem, slik at de derfor forstår de mer av innholdet i kurset, gjenstår å finne ut av. Den konklusjonen vi kan trekke er at for flere av disse 8 studentene var prosjektbasert innføringskurs i statistikk fordelaktig.

Som nevnt over så var det det mest tverrfaglige prosjektet, altså prosjekt tre, som ga mest mersmak for studentene. De kunne kjenne igjen data og problemstilling, og ut fra dette ta skrittet over i analyser og trekke konklusjoner. Flere referanser støtter under observasjonene vi har gjort oss i dette pilotprosjektet, både med den positive effekten av prosjektbasert undervisning (Chen \& Yang, 2019) og av tverrfaglighet (Friedow, Blankenship, \& Green, 2012; Styron, 2013; Ashby \& Exter, 2019).

Utdanningsinstitusjoner helt fra grunnskolenivå og opp til universitetene har nå tverrfaglighet på agendaen. Men for å kunne jobbe prosjektbasert og tverrfaglig finnes det flere utfordringer. En av disse er organisatorisk: Utdanningsinstitusjoner deles ofte inn etter fagfelt, eksempelvis gjennom fakulteter 
(Miller, 2010). Utdanningsplaner er ofte fulle, og de er tilknyttet spesifikke fakulteter eller faggrupper. Betalingsmodellen som utdanningsinstitusjonene baserer seg på fremmer også fagfeltskiller, det kan dermed være utfordrende å få innplassert kurs fra andre fagfelt $i$ andre planer, og å opprette kurs på tvers av fagfelt for å $\varnothing$ ke tverrfagligheten. Det er også store utfordringer knyttet til skalering av slike undervisningsformer. Personlig oppfølging av 8 studenter er gjennomførbart, men med 400 studenter, vil det måtte løses på helt andre måter.

Vi har etter den positive erfaringen og tilbakemeldingen fra det prosjektbaserte kurset innledet et tverrfaglig undervisningsprosjekt sammen med introduksjonskurset i mikrobiologi der vi ønsker å dra nytte av motivasjonen elevene får av fagene til hverandre. Prosjektet er i startfasen og det går i første omgang ut på å lage felles læringsressurser for kursene. Fra litteraturen og egen undervisningserfaring vet vi at studentene tar til seg, blir motivert og ser nytten av statistikkfaget på en helt ny måte når de jobber med eksempler og data som er relevant for sin utdanning og ikke minst har generert selv (BenZvi, Gravemeijer, \& Ainley, 2018). Det er også med på å forberede dem på hvordan man jobber i et forskningsprosjekt: Man starter med et problem man ønsker å løse, tallfester data som skal hjelpe med å svare på problemet (her på laboratoriet i mikrobiologi), gjør analyser av dataene (i statistikkfaget) og kan ut fra disse trekke en konklusjon. Det er selvfølgelig tids- og ressurskrevende for studenter og undervisere å gjennomføre en slik langsgående, tverrfaglig studie i storskala, men å starte med delte læringsressurser slik samarbeidet nå foreligger kan være en god start.

\section{KONKLUSJON}

Til tross for at tverrfaglighet er et uttalt mål på flere nivåer i utdannings-Norge, kan det være utfordrende å få gjennomført. Gjennom prosjekter som vårt, kan vi imidlertid lære mer. Basert på den grundige uttestingen og tilbakemeldingene vi har fătt fra STAT101, har vårt prosjekt med 8 studenter blitt starten på tverrfaglige læringsressurser i statistikk og mikrobiologi ved NMBU. Disse vil komme en bredere studentmasse til gode.

Ikke alle kurs som skal eller bør gjennomføres med prosjektbasert og tverrfaglig undervisning. Men med islett av tverrfaglig tankegang bør tilstrebes. Som Felder og Brent (2016) uthever i sin bok, bør målet for undervisere være å undervise på en inkluderende måte som hjelper så mange studenter som mulig til å lykkes og til å tilegne seg stoffet så godt at det kan nyttiggjøres videre i utdanningen, og dermed også tverrfaglig. Hvor, når, hvordan, og i hvilken grad domene og metode bør møtes i utdanningsløpet, gjenstår til videre diskusjon.

\section{REFERENCES}

Ashby, I., \& Exter , M. (2019). Designing for Interdisciplinarity in Higher Education: Considerations for Instructional Designers. TechTrends, 63, 202-208.

Ben-Zvi, D. (2007). Using Wiki to Promote Collaborative Learning in Statistics Education. Technology Innovations in Statistics Education, 1, 1-18.

Ben-Zvi D., Gravemeijer K., Ainley J. (2018) Design of Statistics Learning Environments. In: Ben-Zvi D., Makar K., Garfield J. (eds) International Handbook of Research in Statistics Education. Springer International Handbooks of Education. Springer, Cham. https://doi.org/10.1007/978-3-31966195-7 16

Biggs, J.B., Tang, C.S.K. (2011). Teaching for quality learning at university. 4th edition. The Society for Research into Higher Education.

Brovold, H. (2014). Invarians drøftet i et nevropsykologisk perspektiv med spesiell referanse til realfag kognisjon. "Fire veier inn i matematikken". Thesis, NTNU, ISSN 1503-8181.

Brovold, H. (2016). Utdanningstesten - med fokus på realfag. Retrieved from The National Center for Science Recruitment: https://utdanningstesten.velgriktig.no/

Chen, C.-H., \& Yang, Y.-C. (2019). Revisiting the effects of project-based learning on students' academic achievement: A meta-analysis investigating moderators. EducationalResearchReview, 26, 71-81.

Felder, R. M., \& Brent, R. (2016). Teaching and Learning STEM - a Practical Guide. San Francisco: Jossey-Bass. 
Friedow, A. J., Blankenship, E. E., \& Green, J. L. (2012). Learning interdisciplinary pedagogies. Pedagogy, 12(3), 405-424.

Karr, E. H. (2017). En studie av klimaendringenes påvirkning på nedbrytning av plantemateriale i et alpint miljø. Retrieved from http://hdl.handle.net/11250/2468169

Ledford, H. (2015). How to solve the world's biggest problems. Nature, 525, 308-311.

Miller, R. (2010). "From the Ground up" Rethinking Engineering Education in the 21st Century. Engineering.

NMBU. (2019). NMBU Strategi 2019-2023. Retrieved from https://www.nmbu.no/om/strategi/2019-2023

NTNU. (2020). Baerekraftig kompetanse - Delrapport: Fremtidens teknologistudier. Trondheim: NTNU. Retrieved from https://www.ntnu.no/documents/1286373847/1289915220/FTS+delrapport+1+$+\mathrm{B} \% \mathrm{C} 3 \%$ A6rekraftig+kompetanse.pdf/

Styron, R. (2013). Interdisciplinary education: a reflection of the real world. Systemics, Cybernetics and Informatics, 11(9), 47-52.

Sæbø, S., Almøy, T., \& Brovold, H. (2015). Does academia disfavor contextual and extroverted students? Uniped, 38, 274-283.

Udir. (2020). Nye lareplaner - grunnskolen og gjennomgående fag vgo. Retrieved from https://www.udir.no/laring-og-trivsel/lareplanverket/Nye-lareplaner-i-grunnskolen-og-gjennomgaendefag-vgo/

Vance, E. A., \& Smith, H. S. (2019). The ASCCR Frame for Learning Essential Collaboration Skills. Journal of Statistics Education, 265-274.

Vinje, H., Almøy, T., Brovold, H., \& Sæbø, S. (2019). Adaptive Statistical Education to Motivate and Enable a Growing and Increasingly Diverse Student Population. IASE 2019 satellite conference - Decision Making Based on Data. Kuala Lumpur. Retrieved from https://iaseweb.org/documents/papers/sat2019/IASE2019\%20Satellite\%20200_VINJE.pdf?1569666572. 